\title{
Photosynthesis and Solution in Formation of Coral Reefs.*
}

\section{By Prof. J. Stanley Gardiner, F.R.S.}

$\mathrm{T}$ $\mathrm{HE}$ old writers on coral reefs such as Chamisso, Darwin, Dana, Semper, L. and A. Agassiz, Murray, and, perhaps, Wharton could scarcely be labelled as belonging to any particular science in a modern sense. In contrast, the investigator of the ' coral reef problem' to-day is usually either a geologist or a zoologist, for the botanist has not understood, up to the present, that he may claim an equal partnership. Unfortunately, the geologist rarely has sufficient knowledge of biology, although well acquainted, perhaps, with the shapes of organisms and the possibilities of earth movements. The biologist, on the other hand, has views as to the disappearance of Gondwanaland; but his writings indicate his incredulity as to any suggested existence of similar earth fluctuations to-day. The mobile crust of the earth allows of movements in the earth's surface ; but these are more often supposed to be activated by chemical processes in the inner material than by alterations in the land and sea above. In addition, there are the physical and chemical reactions of the water of the ocean, and the possibilities of these, little understood even today, are almost unconsidered.

I claim that there are two primarily biological forces found together on all coral reefs and assisting to shape them. Photosynthesis gives an extraordinary biological efficiency to the reef-building organism and, as a result, causes an incredible rapidity of formation of limestone and thus of reef growth. This is countered by the solution of limestone by boring organisms, superficially appearing small in itself, but actually a main factor in that fight between death and life that is visible on every reef.

The photosynthetic method of carbon feeding in most plants, depending on their chlorophyll, is too well known to require further reference. There are many halophilous phanerogams which hold the sand of surface reefs together and thus add materially to their permanency. Bare rock surfaces are covered by aboutforty species of low-growing, mostly blue-green algæ that prevent their destruction.

A few seaweeds such as Halimeda, with precipitated lime in their fronds, assist in forming deposits in the sea and may even be the chief material flling up parts of lagoons. But the main reef-builders are about twelve species of five genera of Lithothamnioneæ, which possess dense skeletons of lime in the composition of which magnesia up to about 20 per cent may play a part. Only a thin surface film is living, the light being unable to penetrate deeply through cells which are ever depositing lime in their walls. The encrusting forms thicken slowly, but push out their edges rapidly, more than $20 \mathrm{~mm}$. being recorded in four weeks. Goniolithon, as finely branching growths, affects the surfaces of barrier and atoll reefs, behind the actual edge

* Substance of a lecture before the Linnean Society of London on Mar. 19.

No. 3214, VoL. 127] zone, which is covered almost entirely by incrust. ing Lithophyllum, pushing up into branching but rounded masses. This genus is abundant in places down to 10 fathoms on the seaward slopes, but gradually Lithothamnion becomes the dominant plant-builder, its deeper species, small-branched but rather delicate detached growths, often completely covering the whole surface. All genera belong to the encircling reef, atoll, or barrier, not occurring on lagoon shoals or floor.

The sedentary animal builders are all cœlenterates. Of first importance are corals (Madreporaria), the builders here being all massive or branching forms, each a single animal but with vast numbers of feeding and breeding organs in its polyps. Then there are the stinging hydroid (Millepora) and the blue coral (Heliopora) which grow generally to form massive upstanding plates, the animal matter forming a surface film perpetually depositing its lime below. The last is an alcyonarian and there must be added a series of forms from this group, the organ-pipe coral (Tubipora) and the soft corals (Sarcophytum, Sclerophytum, Lobophytum, and Xenia), all of which form their lime in spicules which may play a considerable part in sand formation.

In animals, feeding is not so simple as in plants, and consists of three processes concerned with oxygen, carbon, and nitrogen. Oxygen seems to be the hydrogen-acceptor in the respiration of both animals and plants. A complication here is the considerably greater motility of animals, even in sedentary forms, and this implies the necessity of a more bountiful supply of oxygen, as well as the casting out of waste products. The last has been met by the evolution of nephridial kidneys in higher animals, but the excretion is probably a function of all free surfaces in sedentary cœlenterates, calling for a special water circulation to remove such poisonous materials.

These special difficulties in respect to the nutrition of coral-building sedentary animals in tropical waters have been met by the "taming' of unicellular green flagellates (Zooxanthelloe) by the polyps-or the polyps being adopted by such plants-housing them as symbionts in their endoderm cells. In 1896 , at Rotuma I found corals from which oxygen was being given off, and subsequent observations in the Maldives and on the Sladen Expedition convinced me of the importance of this phenomenon, of which Dr. C. M. Yonge, of the Great Barrier Reef Expedition, has recently given experimental proof. Such oxygen production on the part of these symbiotic algæ implies the formation of much carbohydrate material, and in the absence of specially rapid fission in the algæ we may infer the passage of much of this to the polyps. Thus we may suppose the alga to be largely responsible both for the oxygen and for the carbohydrates required by the polyps. But it is possible that the alga is of even greater importance as a scavenger which 
thrives on the waste products of its animal. The utilisation of the animal's carbon dioxide is probably of small importance, for its disposal is easy, and the polyp during the daylight, in which the alga's chlorophyll is alone functional, is largely quiescent. The utilisation of the animal's nitrogenous waste products probably provides the alga with its sole available source of nitrogen, the other salts required quite likely existing as such in the protoplasm of the polyp. In this connexion, the absence of other non-infected kinds of cœlenterates and of Polyzoa, from the shallower waters of coral reefs, is significant.

The depth from which our coral reefs of to-day grow is that at which photosynthesis is active. This is about 60 fathoms for plants and 45 fathoms for the plant animals as maxima. These depths fluctuate in accordance with the turbidity of the water, which increases in the proximity of land masses and decreases in the Pacific and Indian Oceans from east to west, probably in correlation with the eastern influx of polar waters. This turbidity is largely due to unicellular algæ, and a second factor is introduced by their utilisation of any carbon dioxide in the water to the detriment of reef-building organisms. That plants would be affected is clear and it is hard to believe that polyps would provide sufficient carbon, dioxide both for their symbionts and for their lime skeletons. On reefs, the presumption is that their extra requirements are met by their algæ breaking up the bicarbonates of the lime-saturated sea-water; thus amorphous lime may be found precipitated on the tissues of the free parts of the polyps. Where there are active water movements, it is presumably swept away in the consequently heavy mucous lubrication of the surfaces; but in the deeper lagoons and in other areas of still water, the lime clings to the polyps and kills them. This, up to the present, is the only suggestion which explains why lagoons have singularly little coral and algal growth on their floors, and that upgrowing shoals do not occur in lagoons except in the proximity of the passages into them.

The rapidity of growth of coral-building organisms is well known and independent estimates agree that a reef might grow up from 14 fathoms to the surface in a thousand years; but the speed of its deposition is not material to our hypothesis. The horizontal outgrowth of reefs is considerable; but it depends on the extension of their foundations by their own talus material. On the earth's crust below the reef, there is a weight of $2 \frac{1}{2}$ times that of the sea-water replaced by the coral reef, an increase of 150 per cent. Can these or the analogous weight alterations found in the formation of many geological strata be reacting on the earth's crust to produce subsidences? We can give no reply, for we have few data as to the strength of the earth's crust and as to the detailed topography of the oceanic slopes off coral reefs ; but no one with experience of the Pacific Ocean can doubt the activity of crustal movements, even to-day. This question must be tested and it is not beyond the scope of the geophysicist, who should be able to tell us at what depths, below atolls, limestone is underlaid by igneous and other rocks.

Solution of limestones is largely a physicochemical matter and this side has been sufficiently dealt with in respect to the coral reef problem by many workers. Lagoons are supposed to be formed by solution and by the removal of mud in suspension. Generally organisms are only mentioned as providing carbonic acid gas by their decay to help the solution. The mud is accepted as an expected formation wherever land or reefs occur, few observations on its production having been made. Yet this is of great importance, since it entails the study of the decay and grinding up of coral rock in which nearly all the facts are biological, current action not being considerable on reefs that are clothed by living organisms. Every mass of limestone is visibly bored into by organisms-molluses, worms, sipunculids, sea urchins, and certain barnacles. Some of these grind their tunnels, while others dissolve them out, most using both methods.

As a result of the examination of many specimens, I believe it is seldom that more than 40 per cent of the mass is thus removed by these animals. Larger figures were obtained from sponges, but on the whole they are not such important boring organisms in tropical as in temperate seas. But on coral reefs, I find that all limestones, massive rocks, corals, nullipores, stones, and pebbles are penetrated by a network of the finest threads, which are clearly algal in nature. These are the chief boring organisms of coral reefs and the primary cause of the reduction of limestone to pebble, sand, and mud, a whole sequence of organisms aiding them. They bore solely by solution, and while molluscs probably bored primarily for protection, many other forms may well have been seeking for the nutriment these algae provide.

In living corals, the boring hyphæ advance in the corallum so close to the polyps that we can even imagine the latter being thrown down to fend them off. In nullipores, they enter the skeleton less easily and their action is slower and less marked. I have tried by various means to estimate their actions, but the error factor is too great to make any figures of real value, partially because I have not found bored and unbored parts of the same coral skeleton. In undisintegrated coral skeletons, of which the polyps were living, our figures vary from 10 to 60 per cent of the coral dissolved away; while in dead corals of the same species the figures are 40 to 83 per cent. The last figure is exceptional, because usually the coral breaks up into pebbles long before it becomes so reduced; but the boring algæ still live in these, until smothered by mud or consumed by sand-feeding organisms. In any case, the solution of limestone by boring algæ is a primary feature in shaping coral reefs and one deserving of the closest investigation by modern methods applied upon the reefs themselves. In particular, it would be useful to ascertain whether the importance of these forms, observed by me on Maldivan material, is applicable generally to the formation of all coral reefs. 